\title{
IMPLEMENTASI EDUKASI PARENTING DI ERA DIGITAL BAGI MASYARAKAT INDONESIA DI LUAR NEGERI
}

\author{
Mirawati, Winti Ananthia, Endah Silawati, Yeni Yuniarti \\ Universitas Pendidikan Indonesia \\ Correspondence Email: mirawati@upi.edu
}

\begin{abstract}
Parenting has a very important role in the growth and development of children. This paper examines the application of parenting education for Indonesians abroad. This activity involved 14 participants from the Indonesian School of Davao, Philippines. The method used is Participatory Action Research (PAR), which is carried out in a participatory manner with the aim of encouraging changes in the living conditions of participants for the better. The implementation of parenting education in the digital era uses synchronous modes through video conference platforms and asynchronous through the use of websites. The results of this activity showed a positive response from the participants and shared perceptions regarding the importance of care in families and schools, especially for the development of children's character.
\end{abstract}

Keywords:

Parenting, Parenting Education, Digital, Community, Overseas

\begin{abstract}
Abstrak
Pengasuhan memiliki peranan yang sangat penting terhadap pertumbuhan dan perkembangan anak. Artikel ini mengkaji terkait penerapan edukasi parenting bagi masyarakat Indonesia di luar Negeri. Kegiatan ini melibatkan 14 orang partisipan yang berasal dari Sekolah Indonesia Davao, Filipina. Metode yang digunakan yaitu Participatory Action Research (PAR), yang dilaksanakan secara partisipatif dengan tujuan untuk mendorong terjadinya perubahan kondisi hidup partisipan yang lebih baik. Implementasi edukasi parenting di era digital menggunakan moda sinkronus melalui platform video conference dan asinkronus melalui penggunaan website. Adapun hasil dalam kegiatan ini menunjukkan respon positif dari partisipan serta penyamaan persepsi terkait pentingnya pengasuhan dalam keluarga dan sekolah khususnya untuk pengembangan karakter anak.
\end{abstract}

Kata Kunci:

Pengasuhan, Edukasi Parenting, Era Digital, Masyarakat, Luar Negeri

\section{A. Pendahuluan}

Berk (2007) ${ }^{1}$ menyatakan bahwa setiap anggota keluarga akan saling berinteraksi satu sama lain dan memberikan pengaruh baik secara langsung maupun tidak langsung terhadap anggota keluarga lainnya. Lebih lanjut, Berk (2001) ${ }^{2}$ menyatakan bahwa peran orang tua dalam melakukan pengasuhan adalah untuk membantu anak untuk memahami

\footnotetext{
${ }^{1}$ Berk, Laura. (2007). Development through the lifespan. United States of America: Allyn and Bacon.
}

potensi yang dimilikinya dan pengasuhan tersebut dilakukan dengan membuat keputusan untuk lebih responsif, konsisten dan menjalin interaksi yang baik dengan anak. Dengan kata lain, pengasuhan pada anak memiliki kontribusi yang sangat besar terhadap perkembangan anak. Literatur lain yang berkaitan dengan kegiatan pengasuhan oleh orang tua menyatakan bahwa membesarkan dan

2 Berk, Laura. E. (2001). Awakening Children's Minds: How Parents and Teachers Can Make a Difference. New York: Oxford University. 
mengasuh seorang anak merupakan suatu pengalaman yang sangat penting bagi bagi setiap orang tua dan pengasuhan yang dilakukan pada setiap keluarga merupakan suatu hal yang tidak bisa diprediksi (Doughlas, 2014) ${ }^{3}$.

Pengasuhan pada anak merupakan hal yang sangat penting dan memiliki kontribusi yang sangat besar terhadap setiap aspek perkembangan anak. Selain itu, pengasuhan juga sangat berpengaruh terhadap perilaku, kepribadian serta keseimbangan emosi anak (Gordon, 2011; Damayanti, 2011) ${ }^{45}$. Pengasuhan pada anak pertama kali dimulai dalam lingkungan keluarga dan kemudian ditunjang oleh lembaga pendidikan (Suyadi \& Ulfah, 2013) ${ }^{6}$. Hal tersebut menyiratkan bahwa orang tua dan pendidik memiliki peranan yang penting dalam memberikan pengasuhan yang baik pada anak.

Berdasarkan uraian di atas, pengasuhan yang baik pada anak dalam lingkungan keluarga merupakan suatu hal yang mutlak untuk dilakukan, namun sayangnya tidak ada istilah "sekolah orang tua", sehingga orang tua melakukan pengasuhan pada anak biasanya berdasarkan pada pengalaman seperti yang diungkapkan oleh Komalasari $(2013)^{7}$ bahwa seringkali orang tua beranggapan bahwa mengasuh anak berlangsung secara alami dan tidak perlu dipelajari, padahal berdasarkan penelitian yang dilakukan

3 Doughlass, Ann. (2004). The Mother of All Parenting Books. United States of America: Wiley, Hoboken, NJ.

${ }^{4}$ Gordon. A. M \& Browne. K. M (2011). Beginning and Beyond, Foundation in Early Childhood Education, 8th Edition. USA: Wadsworth Cengage Learning.

5 Damayanti, P A (2011). Dinamika perilaku "nakal" anak berambut gimbal di dataran tinggi dieng. Jurnal Psikologi Islam (JPI) Lembaga Penelitian Pengembangan Psikologi dan Keislaman (LP3K), 8 (2), hlm. 165-190. oleh Damayanti (2011) pengasuhan yang dilakukan oleh orang tua membutuhkan kemampuan yang memadai karena pengasuhan tersebut nantinya akan sangat berpengaruh terhadap perilaku, kepribadian serta keseimbangan emosi anak.

Pada umumnya, seperti yang diungkapkan oleh Yusuf (2012) ${ }^{8}$ bahwa orang tua terkadang memberikan perlakuan yang justru akan menghambat perkembangan anak, seperti menekan anak dengan berbagai aturan yang tidak didasarkan pada kepentingan anak atau sebaliknya malah membiarkan dan serba membolehkan apa pun yang diinginkan anak dengan tidak mempertimbangkan keamanan, kebutuhan dan tahapan perkembangan anak, terutama di era digital ini. Permasalahan pengasuhan di era digital yaitu bergesernya peran teknologi informasi dalam pengasuhan. Pengasuhan anak di era digital atau era millenial membutuhkan upaya yang lebih dibanding puluhan tahun yang lalu. Perkembangan dunia digital memang diakui mampu memberi kemudahan bagi kehidupan manusia, namun di sisi lain dapat menciptakan gap/jarak antara orang tua dan anak, yang tak jarang berakhir dengan anak yang membangkang atau masalah

\footnotetext{
${ }^{6}$ Suyadi \& Ulfah. M. (2013). Konsep Dasar PAUD. Bandung: PT Remaja Rosdakarya Berk (2007)

7 Komalasari, E. (2013). Home Visit: Layanan Pendidikan Anak Usia Dini Bagi Anak Kurang Sejahtera. Prosiding Konferensi Pendidikan Anak Usia Dini dan Pendidikan Dasar SPS UPI.

${ }^{8}$ Yusuf. S. (2012). Psikologi Perkembangan Anak dan Remaja. Bandung: PT Remaja Rosdakarya.
} 
perkembangan lainnya lainnya (Safiera, 2016) 9 .

Pengasuhan juga terkadang mengalami kendala kaitan dengan kondisi tertentu, misalnya karena pekerjaan yang memakan waktu relatif lama dan juga faktor sosial budaya yang menjadi tantangan tersendiri, khususnya bagi keluarga migran yang berada di Luar Negeri. Berdasarkan data Rujukan Informasi dan Pengetahuan Pekerja Migran Indonesia, Tenaga Kerja Indonesia yang bekerja di luar negeri sampai tahun 2019 tercatat sebesar 3,7 juta orang dan sekitar 71 persen dari jumlah tersebut bekerja di wilayah Asia Pasifik, sedangkan 28,9 persen lainnya bekerja di wilayah Timur Tengah dan Afrika. Keluarga migran yang berada di luar negeri tersebut tetap harus melaksanakan perannya dalam melakukan pengasuhan yang baik pada anak. Kondisi yang berbeda dengan Indonesia, salah satunya faktor sosial dan budaya menjadi tantangan tersendiri bagi masyarakat Indonesia yang ada di luar negeri dalam melakukan pengasuhan pada anak khususnya di era digital ini.

Penggunaan gadget sebagai pengganti waktu keluarga dalam melakukan pengasuhan saat ini lebih dominan. Istilah "Anak Asuhan Gadget" menjadi hal yang nyata di era digital ini. Masyarakat Indonesia termasuk dalam peringkat lima besar pengguna gadget, khususnya smartphone yang menunjukkan bahwa pengguna aktif sekitar 47 juta. Persentase pengguna gadget yang termasuk kategori usia

\footnotetext{
${ }^{9}$ Safiera, A. (2016). 7 Tips Pengasuhan Anak di Era Digital. [online]: https://wolipop.detik.com. Diakses pada tanggal 01 Maret 2020.

${ }^{10}$ Yusuf. S. (2012). Psikologi Perkembangan Anak dan Remaja. Bandung: PT Remaja Rosdakarya.
}

anak-anak dan remaja masyarakat Indonesia cukup tinggi, yaitu 79,5 persen. Tantangan faktor sosial dan budaya bagi masyarakat Indonesia yang berada di Luar Negeri juga menjadi faktor tantangan lainnya. Masyarakat Indonesia yang berada di luar negeri tentunya akan terlibat langsung dengan konteks sosial budaya dari negara tempat mereka menetap. Hal tersebut tentunya akan berpengaruh terhadap pengasuhan yang perlu dipersiapkan oleh keluarga dalam memberikan pelayanan terbaik bagi perkembangan anak sekaligus menjalankan fungsi keluarga dalam mengenalkan karakter dan melestarikan budaya Indonesia di tengah-tengah kehidupan di Luar Negeri (Yusuf, 2012)10

Solusi yang ditawarkan untuk menangani permasalahan di atas adalah melalui edukasi parenting berbasis daring. Edukasi ini memanfaatkan penggunaan internet untuk keperluan pendidikan, yang mana peserta dan narasumber sepenuhnya terpisah dan tidak diperlukan adanya tatap muka. Seluruh bahan ajar, diskusi, konsultasi, penugasan, latihan, ujian, dan kegiatan pembelajaran lainnya sepenuhnya disampaikan melalui internet/menggunakan sistem jarak jauh.

Metode yang digunakan adalah Participatory Action Research (PAR), yang dilaksanakan secara partisipatif dengan tujuan untuk mendorong terjadinya perubahan kondisi hidup partisipan yang lebih baik (Kemmis, McTaggart \& Nixon, 2014)"1, dalam hal

\footnotetext{
${ }^{11}$ Kemmis, McTaggart \& Nixon. (2014). The Action Research Planner: Doing Critical Participatory Action Research. New York: Springer.
} 
ini yaitu untuk meningkatkan pemahaman dan membangunpersepsi yang sama dengan orang tua dan juga guru terkait pengasuhan bagi anak, khususnya dalam pengembangan karakter. Partisipan yang terlibat dalam kegiatan ini berasal dari masyarakat Indonesia di Davao, Filipina berjumlah empat belas orang.

\section{B. Hasil dan Pembahasan}

\section{Rincian Materi Edukasi}

\section{Parenting}

Materi edukasi parenting disesuaikan dengan kebutuhan partisipan, dalam hal ini perumusan materi edukasi parenting yang sudah diidentifikasi sesuai kebutuhan mitra berdasarkan kuesioner kebutuhan edukasi parenting. Berbagai materi yang dikembangkan dalam kajian ini antara lain sebagai berikut: a. Pembelajaran High Order Thinking Skill untuk mengembangkan karakter anak

b. Multiliterasi dalam penguatan karakter, identitas, dan jati diri Bangsa Indonesia

c. Pengembangan Karakter Anak Melalui Permainan Tradisional

d. Pengasuhan positif dalam pengembangan karakter anak

Berbagai materi tersebut dikembangkan untuk kegiatan parenting yang dilaksanakan secara daring, selain itu materi juga dibuat dalam bentuk video serta booklet parenting. Adapun dokumentasi pelaksanaannya antara lain sebagai berikut:

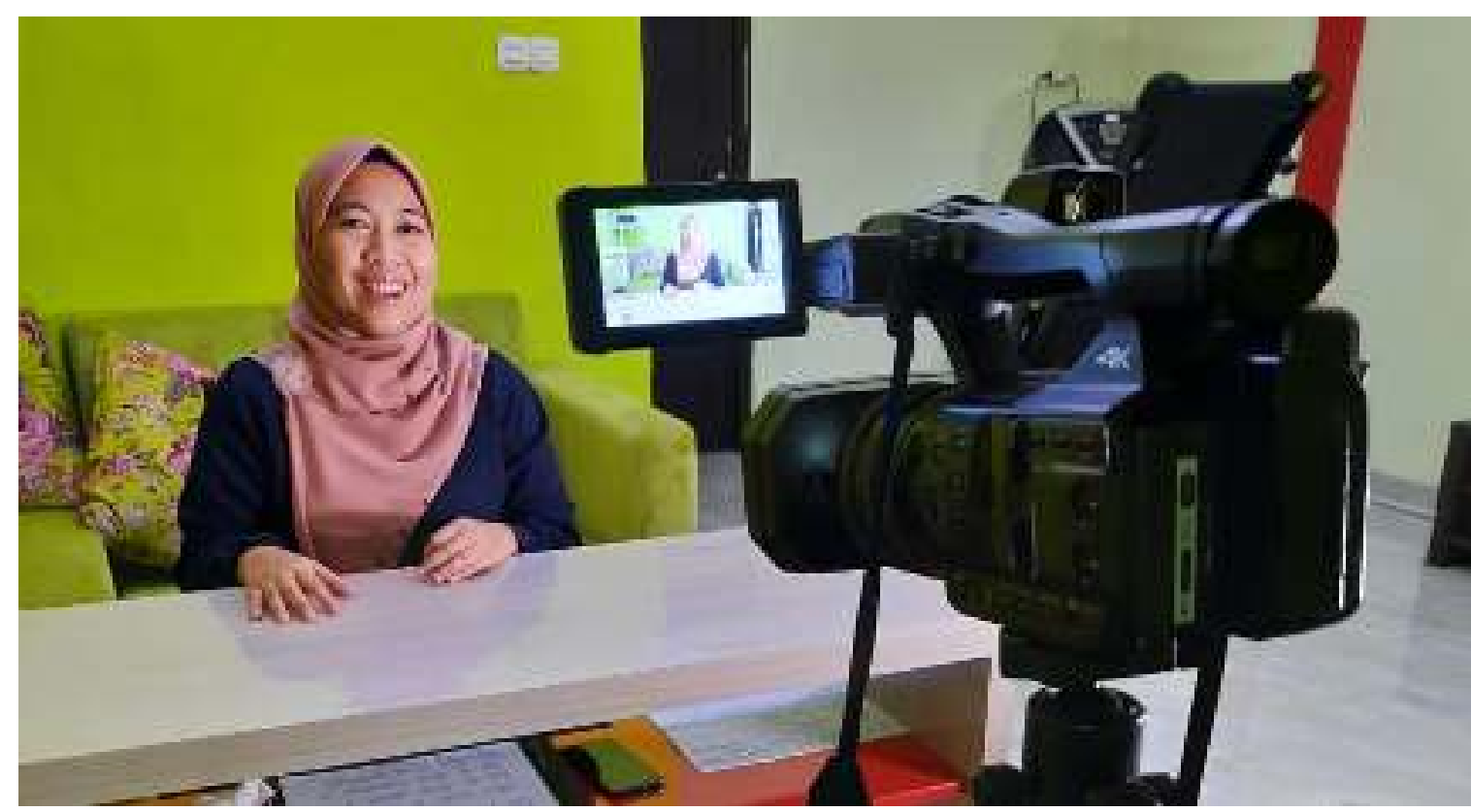

Gambar 1. Proses Pembuatan Video Bahan Materi

\section{Pelaksanaan Edukasi Parenting}

Edukasi parenting di era digital dapat memanfaatkan media daring baik secara sinkronus maupun secara asinkronus, dalam kajian ini yaitu melalui pemanfaatan Web KURMA (Keluarga Unggul,
Ramah, Menyenangkan dan Aman). web KURMA yang merupakan salah satu platform yang nanti akan digunakan dalam pelaksanaan edukasi parenting, khususnya memuat berbagai informasi mulai dari penjelasan program, tim, berita, 
materi materi parenting yang dapat diunduh, video penyampaian materi dan alternatif aktivitas anak.

a. Tampilan Beranda Web

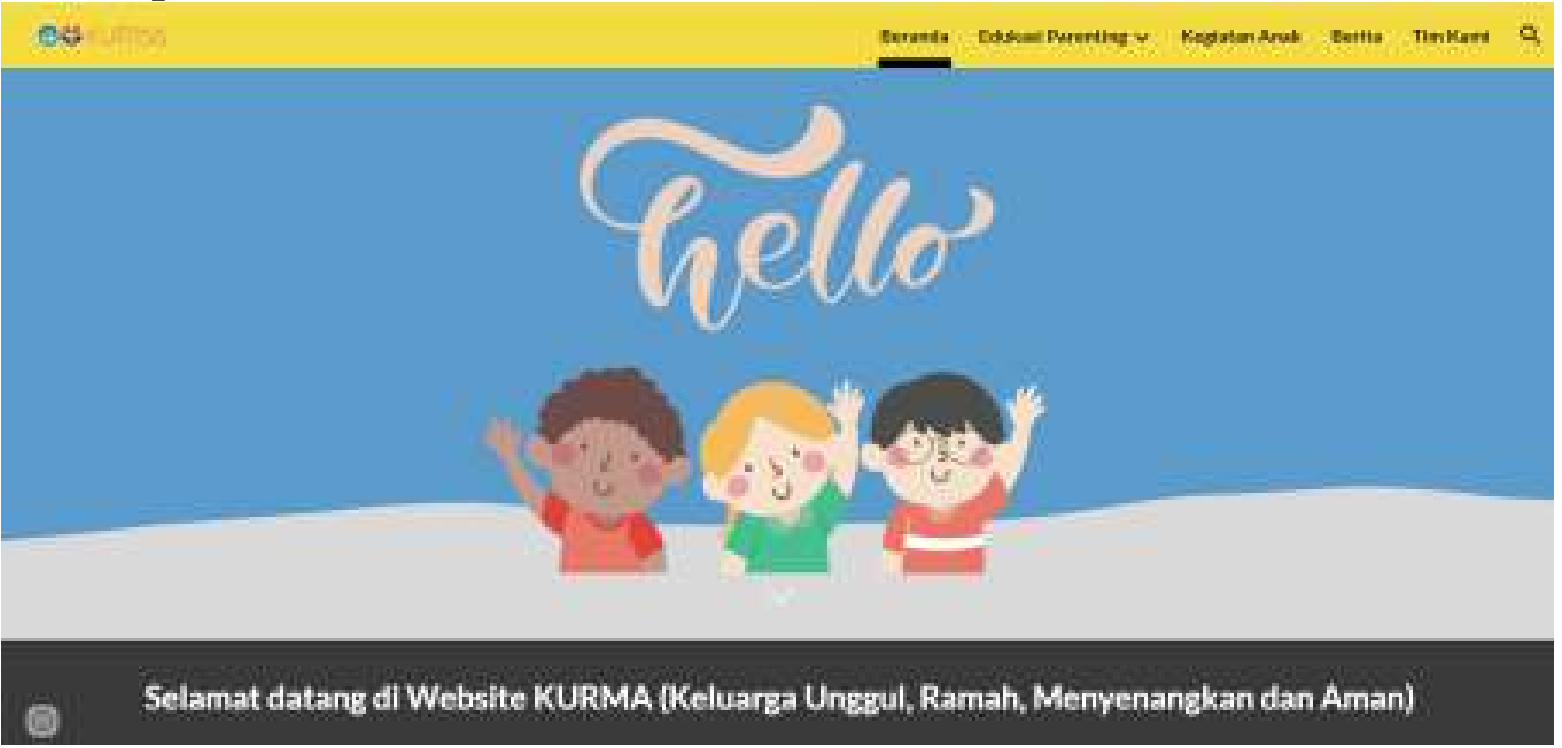

\section{b. Tampilan Penjelasan Program}

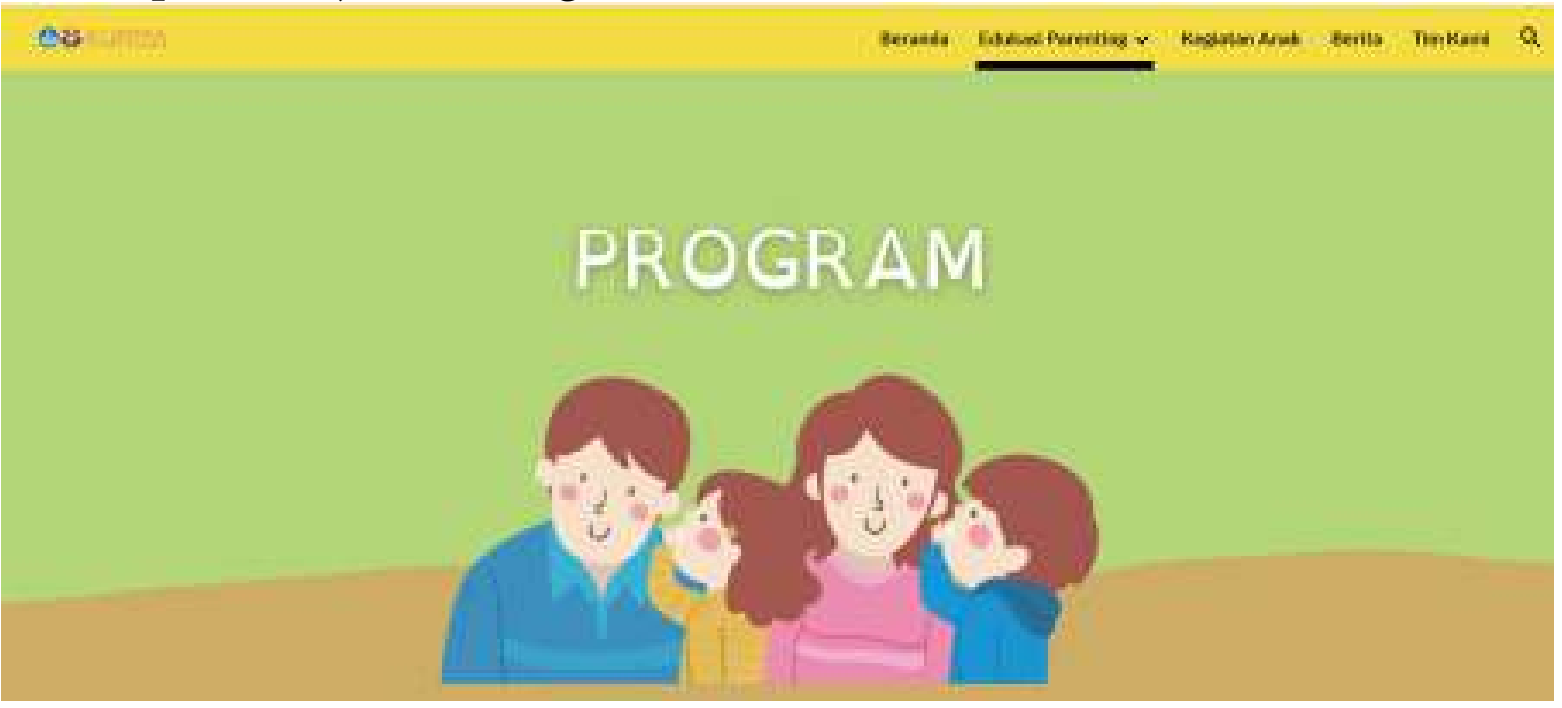

\section{c. Tampilan Target dan Sasaran Program}

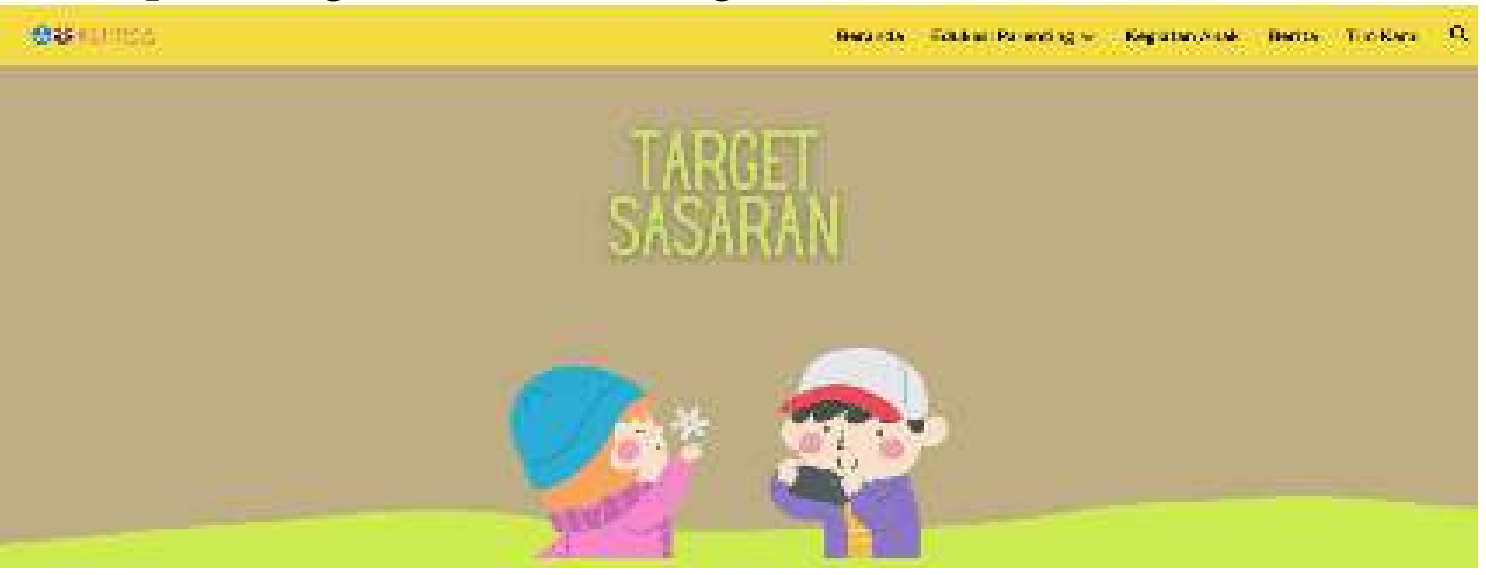


d. Tampilan Unduh Materi Parenting

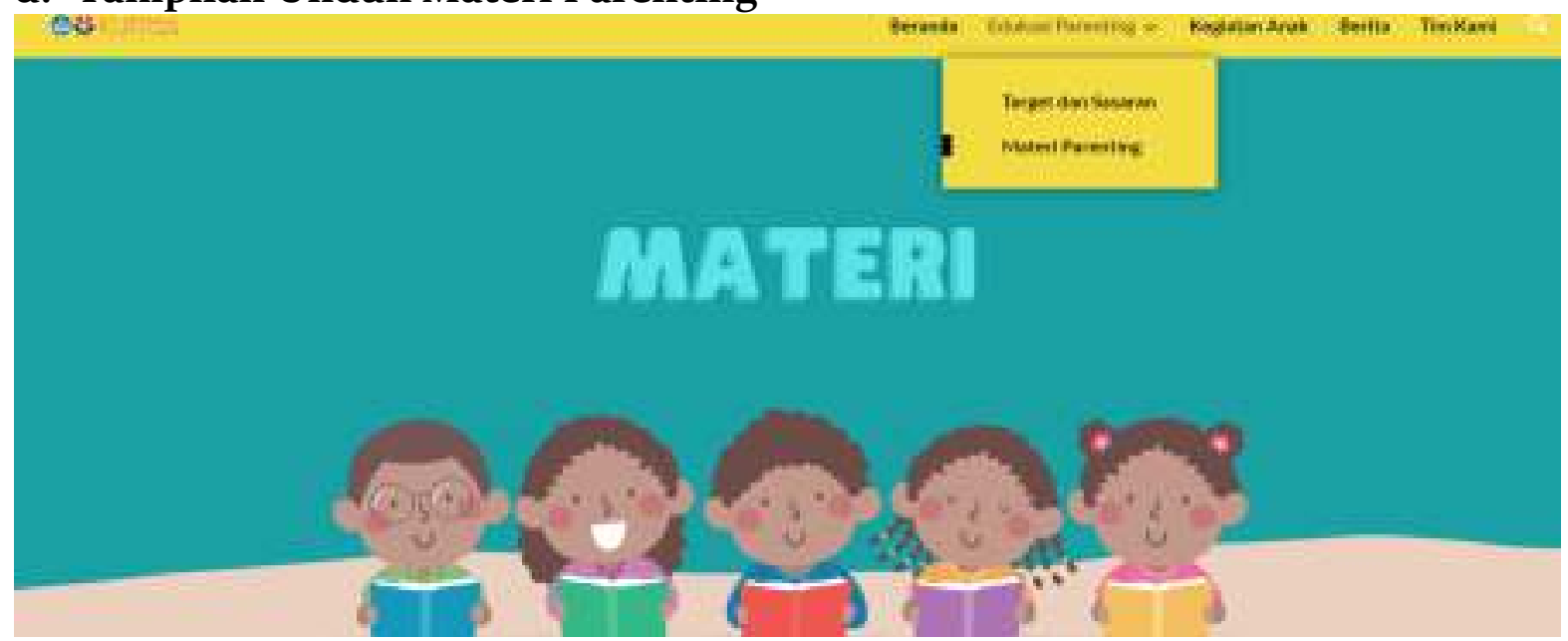

e. Tampilan Alternatif Aktivitas Anak

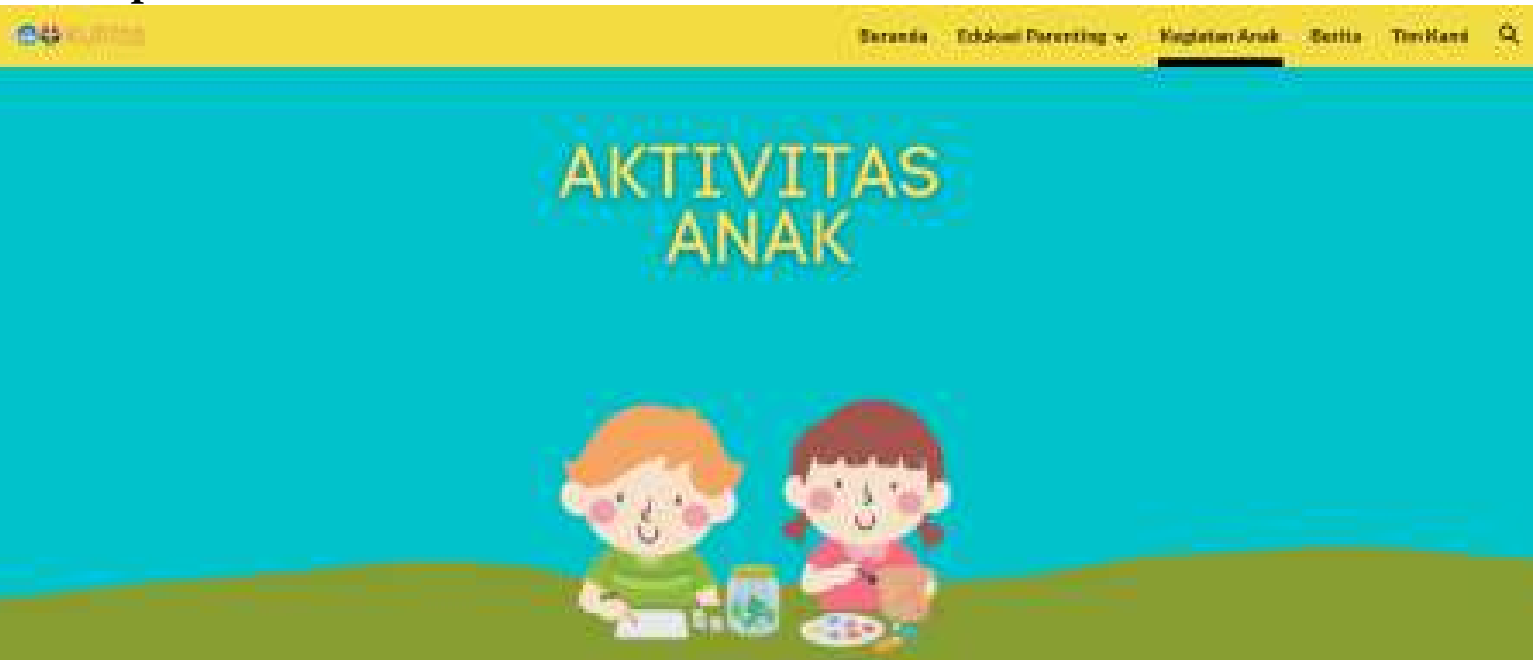

\section{f. Tampilan Berita Kegiatan}

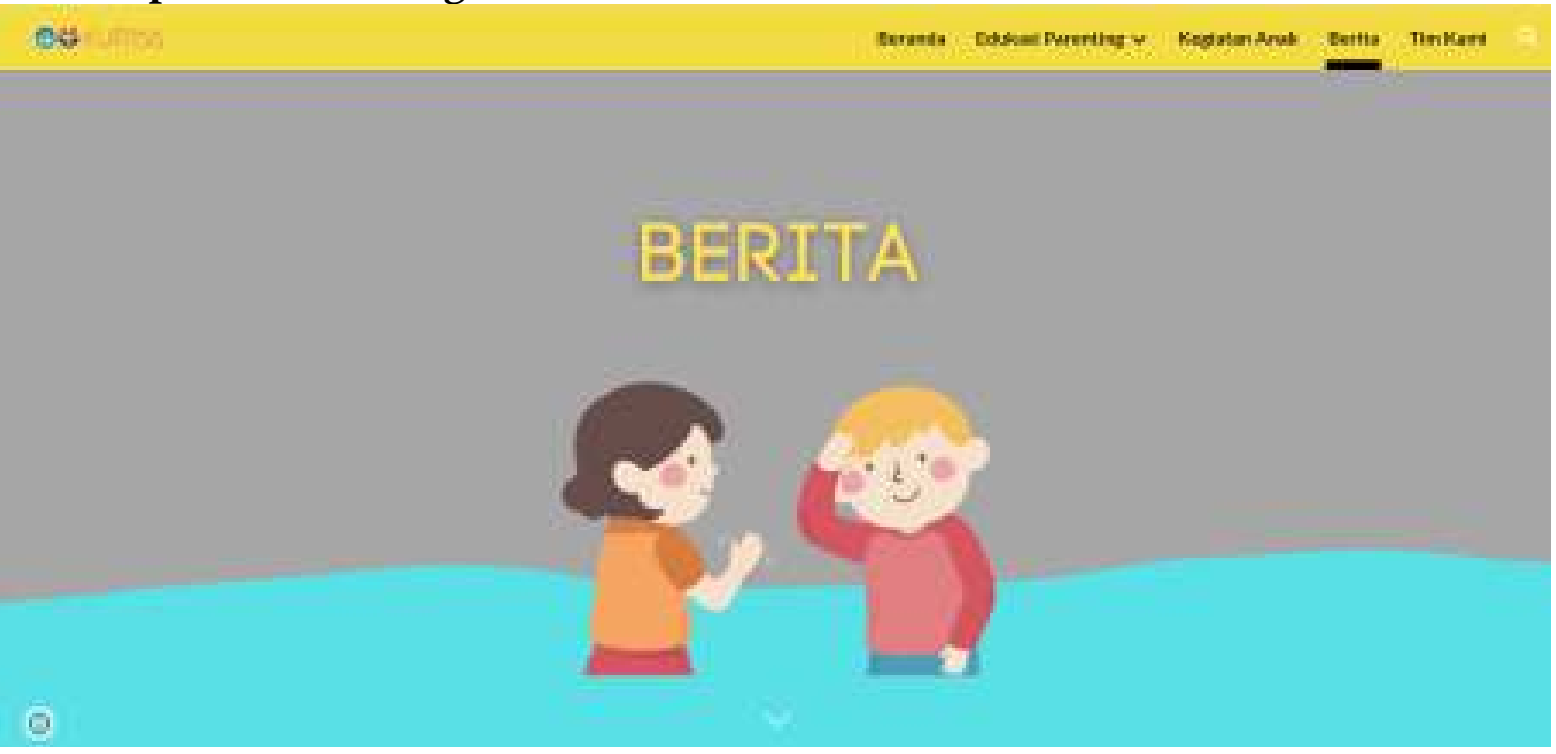




\section{g. Tampilan Tim Pelaksana}

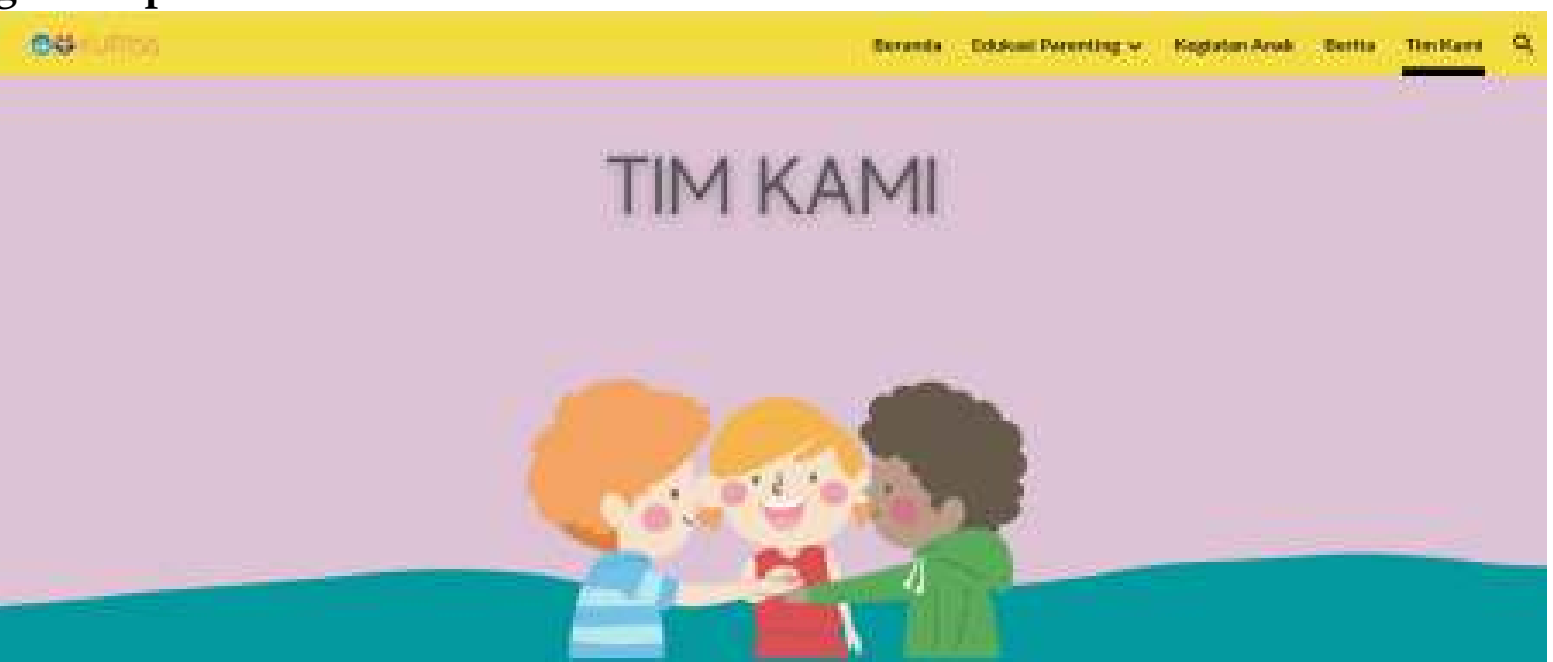

Edukasi parenting yang dilaksanakan secara sinkronus memanfaatkan platform zoom. Kemudahan dalam melakukan interaksi secara maya menjadi salah satu penunjang keberhasilan pelaksanaan program ini. Dokumentasi kegiatannya antara lain sebagai berikut:

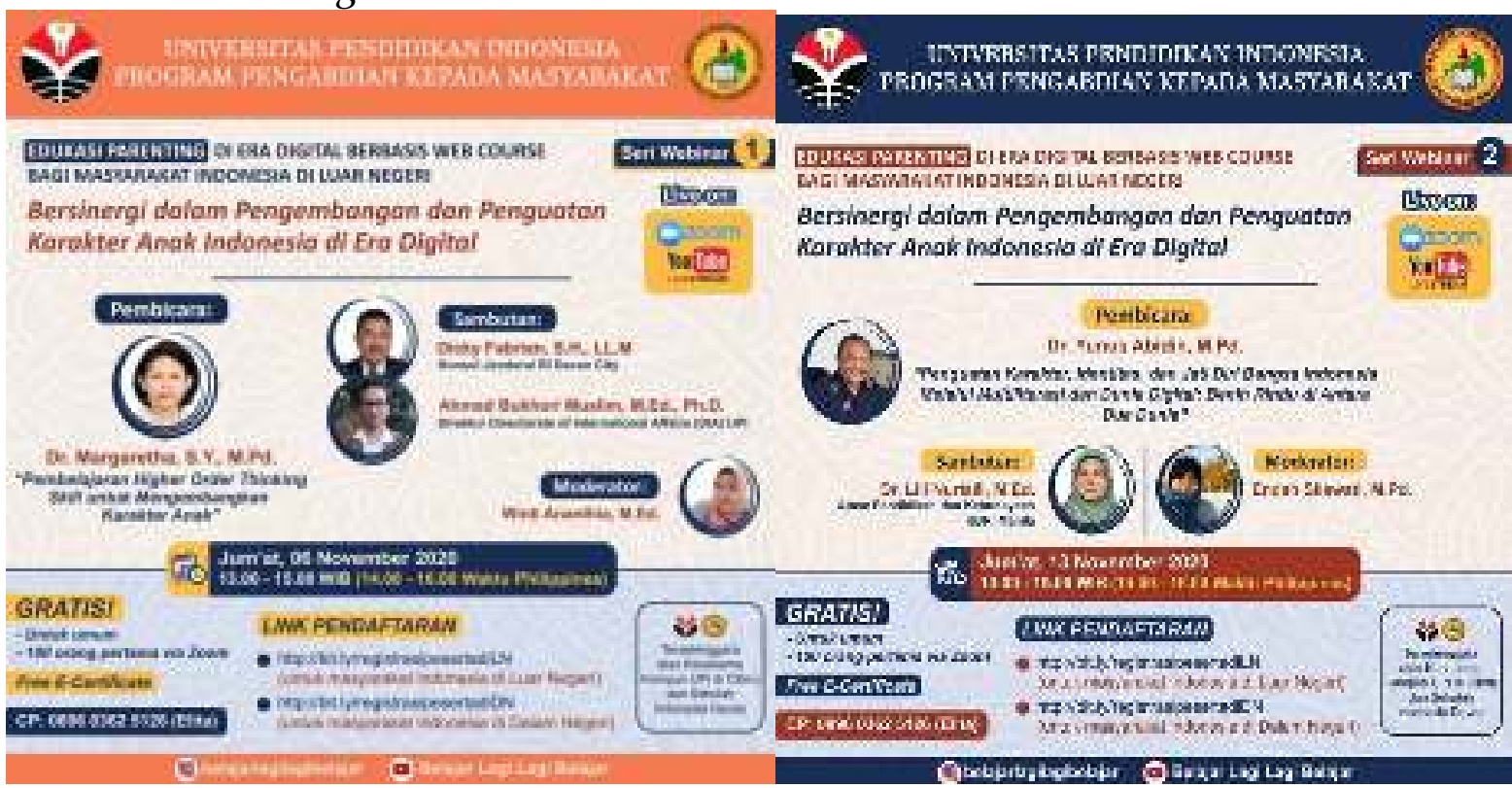




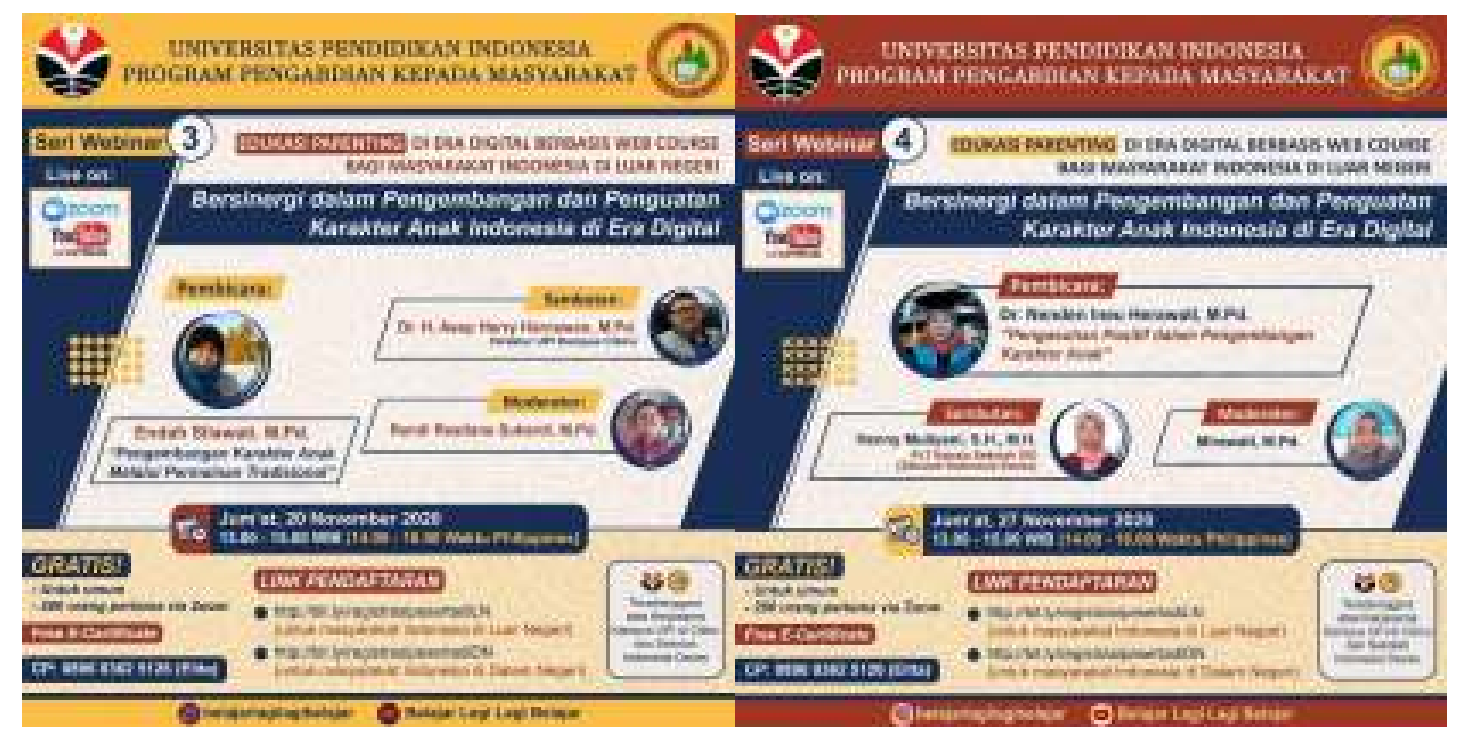

Gambar 2.

\section{Pelaksanaan Edukasi Parenting secara Sinkronus}

3. Hasil Penerapan Edukasi

\section{Parenting}

Hasil penerapan edukasi parenting menunjukkan respon yang positif dari partisipan. Berdasarkan hasil kuesioner yang dibagikan kepada partisipan terkait evaluasi program dan sejauh mana pemahaman yang didapatkannya, sebagian besar menyatakan bahwa informasi terkait pengasuhan pada anak sangat berkaitan erat dengan keseharian dalam keluarga. Partisipan juga mengungkapkan bahwa informasi terkait pengasuhan ini sangat penting didapatkan, mengingat bahwa peran orang tua sangatlah besar. Hal tersebut senada dengan pendapat (Suyadi \& Ulfah, 2013) $)^{12}$ bahwa orang tua dan pendidik memiliki peranan yang penting dalam memberikan pengasuhan yang baik pada anak.

\section{Simpulan}

Berdasarkan seluruh uraian di atas, dapat disimpulkan bahwa penerapan edukasi parenting dapat membantu orang tua atau guru lebih memahami konsep terkait pengasuhan pada anak, khususnya dalam pengembangan karakter. Selain itu, pelaksanaan edukasi parenting di era digital dapat memanfaatkan perangkat teknologi informasi sehingga dapat menjangkau lebih luas bagi masyarakat Indonesia, khususnya yang berada di Luar Negeri.

\section{DAFTAR PUSTAKA}

Berk, Laura. (2007). Development through the lifespan. United States of America: Allyn and Bacon.

Berk, Laura. E. (2001). Awakening Children's Minds: How Parents and Teachers Can Make a Difference. New York: Oxford University.

Damayanti, P A (2011). Dinamika perilaku "nakal" anak berambut gimbal di dataran tinggi dieng.

${ }^{12}$ Suyadi \& Ulfah. M. (2013). Konsep Dasar PAUD. Bandung: PT Remaja Rosdakarya Berk (2007) 
Jurnal Psikologi Islam (JPI)

Lembaga

Penelitian

Pengembangan Psikologi dan

Keislaman ( $\left.\mathrm{LP}_{3} \mathrm{~K}\right), 8$ (2), hlm. 165-19o.

Doughlass, Ann. (2004). The Mother of All Parenting Books. United States of America: Wiley, Hoboken, NJ.

Gordon. A. M \& Browne. K. M (2011). Beginning and Beyond, Foundation in Early Childhood Education, 8th Edition. USA: Wadsworth Cengage Learning.

Kemmis, McTaggart \& Nixon. (2014). The Action Research Planner: Doing Critical Participatory Action Research. New York: Springer.

Komalasari, E. (2013). Home Visit: Layanan Pendidikan Anak Usia
Dini Bagi Anak Kurang Sejahtera. Prosiding Konferensi Pendidikan Anak Usia Dini dan Pendidikan Dasar SPS UPI.

Rudiyanto. (2010). Pemberdayaan

Masyarakat dalam

Penyelenggaraan PAUD.

Bandung: Program Pendidikan

Guru Pendidikan Anak Usia Dini UPI.

Safiera, A. (2016). 7 Tips Pengasuhan Anak di Era Digital. [online]: https://wolipop.detik.com.

Diakses pada tanggal o1 Maret 2020.

Suyadi \& Ulfah. M. (2013). Konsep Dasar PAUD. Bandung: PT Remaja Rosdakarya Berk (2007)

Yusuf. S. (2012). Psikologi Perkembangan Anak dan Remaja. Bandung: PT Remaja Rosdakarya. 